\title{
Protein Engineering of Venom Toxins by Synthetic Approach and NMR Dynamic Simulation: Status of Basic Amino Acid Residues in Waglerin I
}

\author{
Yu-Mei Hsiao,* Chyh-Chong Chuang, $\dagger$ Li-Chin Chuang, $\dagger$ Hui-Ming Yu, $\dagger$ \\ Kung-Tsung Wang, ${ }^{*} \dagger$ Shyh-Horng Chiou, ${ }^{*} \dagger$ and Shih-Hsiung Wu ${ }^{*},+$,
}

$\dagger$ Institute of Biological Chemistry, Academia Sinica, Taipei, Taiwan; and *Institute of Biochemical Sciences, P.O. Box 23-106, National Taiwan University, Taipei, Taiwan

Received August 9, 1996

\begin{abstract}
The tertiary structure of waglerin I has been determined by NMR and dynamic simulated annealing [Chuang et al., Biochim. Biophys. Acta 1292, 145-155 (1996)]. It is believed that the peptide basicity of waglerin may play an important role for its activity due to its high content of basic amino acids. In order to investigate the active site of the toxin, seven analogues of waglerin, $\left[\mathrm{Ala}^{3}\right]$-waglerin, $\left[\mathrm{Ala}^{7}\right]$-waglerin, $\left[\mathrm{Ala}^{10}\right]$-waglerin, $\left[\mathrm{Ala}^{14}\right]$-waglerin, $\left[\mathrm{Ala}^{18}\right]$-waglerin, $\left[\mathrm{Ala}^{20}\right]$-waglerin and $\left[\mathrm{Ala}^{22}\right]$-waglerin have been synthesized chemically by single replacement of basic amino acid residues one by one with Ala. By correlation of structures for each analogue with $\mathrm{LD}_{50}$ toxicity bioassays, it is found that the $\left[\mathrm{Ala}^{10}\right]$-waglerin exhibits no toxicity and the active site of the native toxin seems to reside in the proximity of the disulfide loop, which is spatially close to $\mathrm{His}^{10}$. Furthermore, the closer is the disulfide loop to the basic amino acid in waglerin, the more influential is the basic amino acid on the toxicity of waglerin. Based on the tertiary structure of waglerin, the structures of all synthetic analogues were derived based on computer-simulated modelling. By the pair-wise structural comparison, the disulfide loop in $\left[\mathrm{Ala}^{10}\right]$-waglerin analogue is found to be twisted as compared to the native form, in agreement with the lack of toxicity for this synthetic analogue. $\odot 1996$ Academic Press, Inc.
\end{abstract}

Waglerin was first isolated from Trimeresurus wagleri, a small toxic arboreal snake distributed from Malaysia, the Philippines, Thailand and the Indo-Australian archipelago to Indonesia [1]. It is a peptide toxin composed of 22 amino-acid residues with one disulfide bond [2,3]. The amino acid sequence of the toxin is shown in Fig. 1. Most noteworthy is the salient feature of the amino acid composition of waglerin, which contains seven proline residues out of 22 amino acids and a high content of basic amino acids. According to the previous report [3], the intramolecular disulfide bond in this toxic peptide is shown to be essential for its biological activity. The detailed mechanism for the toxic action of waglerins has not yet been fully elucidated. In preliminary studies, the toxin appears to resemble some vasoactive peptides or neurotoxins. However, the toxin lacks any antigenic identity with a number of representative neurotoxins and myotoxins.

Recently, several groups have reported multiple functions for this toxin [4-7]. Respiratory failure is shown to be the primary cause of death from the toxin in mice, yet rats are rather resistant to waglerin I [5]. The toxin $(10 \mu \mathrm{g} / \mathrm{ml})$ does not alter the amplitude of sodium and potassium currents at the nerve endings, however it causes a decrease in the calcium current $[7,8]$. The toxin acts at both pre- and post-synaptic neuromuscular junctions of the mouse motor endplate and its presynaptic effect is shown to be more potent than the postsynaptic one. Thus, any hypotensive effect could be secondary to peripheral neurotoxicity [4]. In the

${ }^{1}$ Corresponding address: S.-H. Wu, Institute of Biological Chemistry, Academia, P.O. Box 23-106, Taipei, Taiwan. Fax: (886)-2-3635038. E-mail: shwu@gate.sinica.edu.TW. 


\begin{tabular}{|c|c|c|c|c|c|c|c|c|c|c|c|c|c|c|c|c|c|c|c|c|c|c|}
\hline & & & & & 5 & & & & & 10 & & & & & 15 & & & & & 20 & & \\
\hline Waglerin I & G & $\mathrm{G}$ & $\mathrm{K}$ & $\mathrm{P}$ & $\mathrm{D}$ & $\mathrm{L}$ & $\mathrm{R}$ & $\mathrm{P}$ & $\mathrm{C}$ & $\mathrm{H}$ & $\mathrm{P}$ & $\mathrm{P}$ & $\mathrm{C}$ & $\mathrm{H}$ & $\mathrm{Y}$ & I & $P$ & $\mathrm{R}$ & $\mathrm{P}$ & $\mathrm{K}$ & $\mathrm{P}$ & $\mathrm{R}$ \\
\hline Waglerin II ([Tyr $\left.{ }^{10}\right]$-waglerin I) & G & $G$ & $\mathrm{~K}$ & $\mathrm{P}$ & $\mathrm{D}$ & $\mathrm{L}$ & $\mathrm{R}$ & $\mathrm{P}$ & $\mathrm{C}$ & $\mathbf{Y}$ & $\mathrm{P}$ & $\mathrm{P}$ & $\mathrm{C}$ & $\mathrm{H}$ & $\mathrm{Y}$ & $\mathrm{I}$ & $\mathrm{p}$ & $\mathrm{R}$ & $\mathrm{P}$ & $\mathrm{K}$ & $P$ & \\
\hline$\left[\mathrm{Ala}^{3}\right]$-waglerin I & $\mathrm{G}$ & $\mathrm{G}$ & $\mathbf{A}$ & $\mathrm{P}$ & $\mathrm{D}$ & $\mathrm{L}$ & $\mathrm{R}$ & $\mathrm{P}$ & $\mathrm{C}$ & $\mathrm{H}$ & $\mathrm{P}$ & $\mathrm{P}$ & $\mathrm{C}$ & $\mathrm{H}$ & $\mathrm{Y}$ & I & $\mathrm{P}$ & $\mathrm{R}$ & $\mathrm{P}$ & $\mathrm{K}$ & $\mathrm{P}$ & \\
\hline$\left[\mathrm{Ala}^{7}\right]$-waglerin I & $G$ & $\mathrm{G}$ & $\mathrm{K}$ & $\mathrm{P}$ & $\mathrm{D}$ & $\mathrm{L}$ & $\mathbf{A}$ & $\mathrm{P}$ & C & $\mathrm{H}$ & $\mathrm{P}$ & $\mathrm{P}$ & $\mathrm{C}$ & $\mathrm{H}$ & $\mathrm{Y}$ & I & $P$ & $\mathrm{R}$ & $\mathrm{P}$ & $\mathrm{K}$ & $P$ & \\
\hline$\left[\mathrm{Ala}^{10}\right]$-waglerin I & $\mathrm{G}$ & $\mathrm{G}$ & $\mathrm{K}$ & $\mathbf{P}$ & $\mathrm{D}$ & $\mathrm{L}$ & $\mathrm{R}$ & $\mathrm{P}$ & C & $\mathbf{A}$ & $\mathrm{P}$ & $P$ & $\mathrm{C}$ & $\mathrm{H}$ & $\mathrm{Y}$ & I & $P$ & $\mathrm{R}$ & $\mathrm{P}$ & $\mathrm{K}$ & $\mathrm{P}$ & \\
\hline$\left[\mathrm{Ala}^{14}\right]$-waglerin I & $\mathrm{G}$ & $\mathrm{G}$ & $\mathrm{K}$ & $\mathrm{P}$ & $\mathrm{D}$ & $\mathrm{L}$ & $\mathrm{R}$ & $\mathrm{P}$ & $\mathrm{C}$ & $\mathrm{H}$ & $\mathrm{P}$ & $\mathrm{P}$ & $\mathrm{C}$ & $A$ & $\mathrm{Y}$ & I & $P$ & $\mathrm{R}$ & $\mathrm{P}$ & $\mathrm{K}$ & $P$ & \\
\hline$\left[\mathrm{Ala}^{18}\right]$-waglerin I & $\mathrm{G}$ & $\mathrm{G}$ & $\mathrm{K}$ & $\mathrm{P}$ & D & $\mathrm{L}$ & $\mathrm{R}$ & $P$ & C & $\Pi$ & $\mathrm{P}$ & $P$ & $\mathrm{C}$ & $\mathrm{H}$ & $\mathrm{Y}$ & I & $P$ & $A$ & $P$ & $\mathrm{~K}$ & $P$ & \\
\hline$\left[\mathrm{Ala}^{20}\right]$-waglerin I & G & G & $\mathrm{K}$ & $\mathrm{P}$ & $\mathrm{D}$ & $\mathrm{L}$ & $\mathrm{R}$ & $P$ & $\mathrm{C}$ & & $\mathrm{P}$ & $\mathrm{P}$ & C & $\mathrm{H}$ & $\mathrm{Y}$ & I & $\mathrm{P}$ & $\mathrm{R}$ & $\mathrm{P}$ & $\mathbf{A}$ & $P$ & \\
\hline $\left.\mathrm{Ala}^{22}\right]$-waglerin I & $\mathrm{G}$ & $\mathrm{G}$ & $\mathrm{K}$ & $\mathrm{P}$ & D & $\mathrm{L}$ & $\mathrm{R}$ & $\mathrm{P}$ & $\mathrm{C}$ & & $\mathrm{P}$ & $\mathrm{P}$ & $\mathrm{C}$ & $\mathrm{H}$ & $\mathrm{Y}$ & I & $\mathrm{P}$ & & $\mathrm{P}$ & $\mathrm{K}$ & & \\
\hline
\end{tabular}

FIG. 1. Amino acid sequences of waglerin-I, waglerin-II and various synthetic analogues.

present study, seven analogs of waglerin were synthesized by replacement of various basic amino acids with alanine in an endeavour of elucidating the molecular basis underlying its biological activity. We have also applied NMR analysis and dynamic simulated annealing to derive three-dimensional structures for each synthetic analogue in order to make a defined structure/activity comparison based on the different spatial organizations of engineered toxins.

\section{MATERIALS AND METHODS}

Chemical synthesis of waglerin analogues. Waglerin analogues were synthesized by solid-phase peptide synthesis using an ABI automated peptide synthesizer. Starting with $0.25 \mathrm{mmol}(0.295 \mathrm{~g})$ of $\mathrm{HMP}$ resin $(0.85 \mathrm{mmol} / \mathrm{g})$, the syntheses were carried out in a stepwise Fast MocTM protocol. The amino acids were introduced using the manufacturer's prepacked cartridges (1 mmol each). Side chain protecting groups used were arginine (Pmc), aspartic acid (OtBu), cysteine (Trt), histidine (Trt), lysine (Boc), tyrosine (tBu); Pmc, 2,2,5,7,8-pentamethylchroman-6-sulfonyl; Trt, trityl; $\mathrm{OtBu}$, tert-butyl ester; Boc, t-butyloxycarbonyl; tBu, tert-butyl. Double coupling was used for arginine (Pmc) and proline. After synthesis, $0.54 \mathrm{~g}$ peptide resin was placed in a round-bottom flask containing a micro stirring-bar. The cool mixture containing $0.75 \mathrm{~g}$ crystalline phenol, $0.25 \mathrm{ml}$ EDT, $0.5 \mathrm{ml}$ thioanisole, $0.5 \mathrm{ml}$ deionized $\mathrm{H}_{2} \mathrm{O}$ and $10 \mathrm{ml}$ TFA was put into the flask. After stirring at room temperature for 2-3 h, the reaction mixture was concentrated on a rotary evaporator and the temperature of the water bath was maintained below $40^{\circ} \mathrm{C}$ to prevent damage to the peptide that might have been caused by heat. Dichloromethane $(10-20 \mathrm{ml})$ was added to help the solution evaporate. The residue was further lyophilized. Then the residue was rinsed with cold ether, filtered, and washed with about $200 \mathrm{ml}$ cold ether. The filtered residue was immediately transferred to 1.7 liters of a stirred solution of dilute acetic acid $\left(0.4 \% \mathrm{AcOH}\right.$ in $\left.\mathrm{H}_{2} \mathrm{O}\right)$. After stirring for several min, the $\mathrm{pH}$ of the solution was adjusted to $\mathrm{pH} 8.0$ with ammonium hydroxide. After filtration to remove resin, the solution was maintained without stirring at room temperature for $4 \mathrm{~h}$. Analytical HPLC was used to monitor the progress of oxidation. The oxidized solution was then lyophilized. The product was dissolved with $0.4 \%$ acetic acid solution and filtered to remove the insoluble material. The filtrate was purified by HPLC using a $\mathrm{C}_{18}$ column $(10 \mu \mathrm{m}$ particle size, $250 \times 4.6 \mathrm{~mm})$ with a gradient $(0 \rightarrow 17 \rightarrow 22 \rightarrow 50 \%$ solvent $\mathrm{B}$ in four steps of $0 \rightarrow 5 \rightarrow 20 \rightarrow 25 \mathrm{~min}$ respectively) using solvent A (acetonitrile/ $\mathrm{H}_{2} \mathrm{O} /$ trifluoroacetic acid (TFA) $=5$ / $95 / 0.1$ ) and solvent $\mathrm{B}$ (acetonitrile/ $\mathrm{H}_{2} \mathrm{O} / \mathrm{TFA}=90 / 10 / 0.1$ ) at a flow rate of $1 \mathrm{ml} / \mathrm{min}$ and monitored by absorbance at $214 \mathrm{~nm}$.

The synthetic peptides were characterized by ion-spray mass spectroscopy and amino acid analysis. Mass spectra were determined by a VG Bio-Q Mass Spectrometer with an electrospray ion source. The amino acid compositions of the synthetic peptides were analyzed on a Beckman 6300 High Performance Analyzer.

Bioassay (lethal dose at 50\% fatality, $L D_{50}$ ). Mice (NIH strain, 16-22 g) were injected (i.p.) with synthetic peptides dissolved in $0.04 \mathrm{ml}$ of $0.9 \% \mathrm{NaCl}$ isotonic solution and observed for $24 \mathrm{~h}$. Five doses of the peptides ranging from 0.1 to $1.0 \mu \mathrm{g} / \mathrm{g}$ ( or other doses depending on the initial experimental results) are chosen for lethality experiments. Different doses of various peptides were tested on eight mice. $\mathrm{LD}_{50}$ values and their corresponding statistical $95 \%$ confidence limits were calculated according to the method of Lithchfield and Wilcoxon [9].

NMR dynamic simulated annealing and molecular modeling. The coordinates of waglerin-I which has been determined by 2D-NMR and molecular modeling in our lab [10] was used as the template for model building of all seven waglerin-I analogues by employing the Homology module (Version 2.3) integrated in the graphics program INSIGHT 
(a)

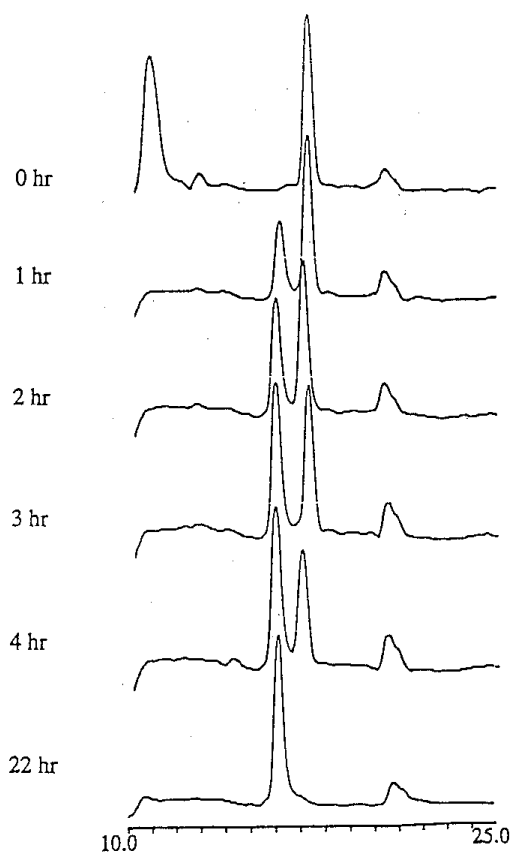

(b)

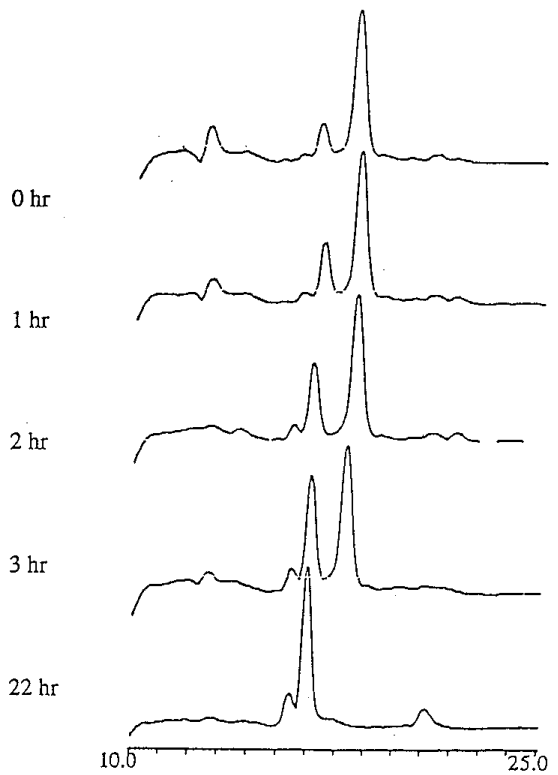

FIG. 2. HPLC time-course profiles for the analysis of oxidation: (a) $\left[\mathrm{Ala}^{10}\right]$-waglerin and (b) $\left[\mathrm{Ala}^{14}\right]$-waglerin. HPLC analyses were carried out in a reverse-phase C18 column $(250 \times 4.6 \mathrm{~mm})$ with conditions as described in Materials and Methods. In contrast to a previous report [12] all synthetic analogues of waglerin-I possess similar oxidation/refolding rates.

II (Biosym Technologies, Inc., San Diego) on a Silicon Graphics 4D/35G workstation. For an analogue, a fragment of three residues, the mutated one and its two neighboring two residues, was assigned as SVR (structural variable region) and its adjacent two peptide fragments were assigned as SCRs (structural conserved regions). The coordinates of the SCRs were directly copied from the template. The SVR was built using a loop generation method (Homology version 2.3, Biosym 1993) of Shenkin et al. [11], and the one with the smallest RMS deviation was chosen as the suitable model from all generated candidates for the loop conformation. The splices between the SCRs and SVR were smoothened by Discover program with CVFF force field and relaxed by minimization. All built models were further

TABLE 1

Toxicity (i.p. $\mathrm{LD}_{50}$ ) of Waglerin I and Its Analogues

\begin{tabular}{|c|c|c|}
\hline Sample & $\begin{array}{l}\text { i.p. } \mathrm{LD}_{50} \\
(\mathrm{mg} / \mathrm{kg})\end{array}$ & $\begin{array}{c}\text { Potency ratio } \\
\left(\mathrm{LD}_{50} \text { of analogue/LD } / \mathrm{D}_{50} \text { of waglerin I) }\right.\end{array}$ \\
\hline Normal saline & All alive & (Negative control) \\
\hline Waglerin I & $0.4(0.4-0.5)$ & 1 (Positive control) \\
\hline$\left[\mathrm{Ala}^{3}\right]$-waglerin I & $0.5(0.4-0.5)$ & $1.0(0.8-1.2)$ Same potency \\
\hline$\left[\mathrm{Ala}^{7}\right]$-waglerin I & $1.4(1.1-1.9)$ & $3.2(2.3-4.4)$-Significant \\
\hline$\left[\mathrm{Ala}^{10}\right]$-waglerin I & $>15.1$ & $>33.6$ - Most significant \\
\hline$\left[\mathrm{Ala}^{14}\right]$-waglerin I & $7.4(5.7-9.5)$ & $16.4(12.1-22.2)-$ More significant \\
\hline$\left[\mathrm{Ala}^{18}\right]$-waglerin I & $2.2(1.9-2.6)$ & $4.9(4.0-6.2)$ - Significant \\
\hline$\left[\mathrm{Ala}^{20}\right]$-waglerin I & $1.1(0.9-2.1)$ & $3.0(1.9-4.8)$-Significant \\
\hline$\left[\mathrm{Ala}^{22}\right]$-waglerin I & $0.7(0.6-0.9)$ & $1.5(1.2-2.0)$-Less significant \\
\hline $\begin{array}{l}{\left[\mathrm{Tyr}^{100}\right] \text {-waglerin I }} \\
\text { (Waglerin II) }\end{array}$ & $>15.1$ & $>33.6$ - Most significant \\
\hline
\end{tabular}




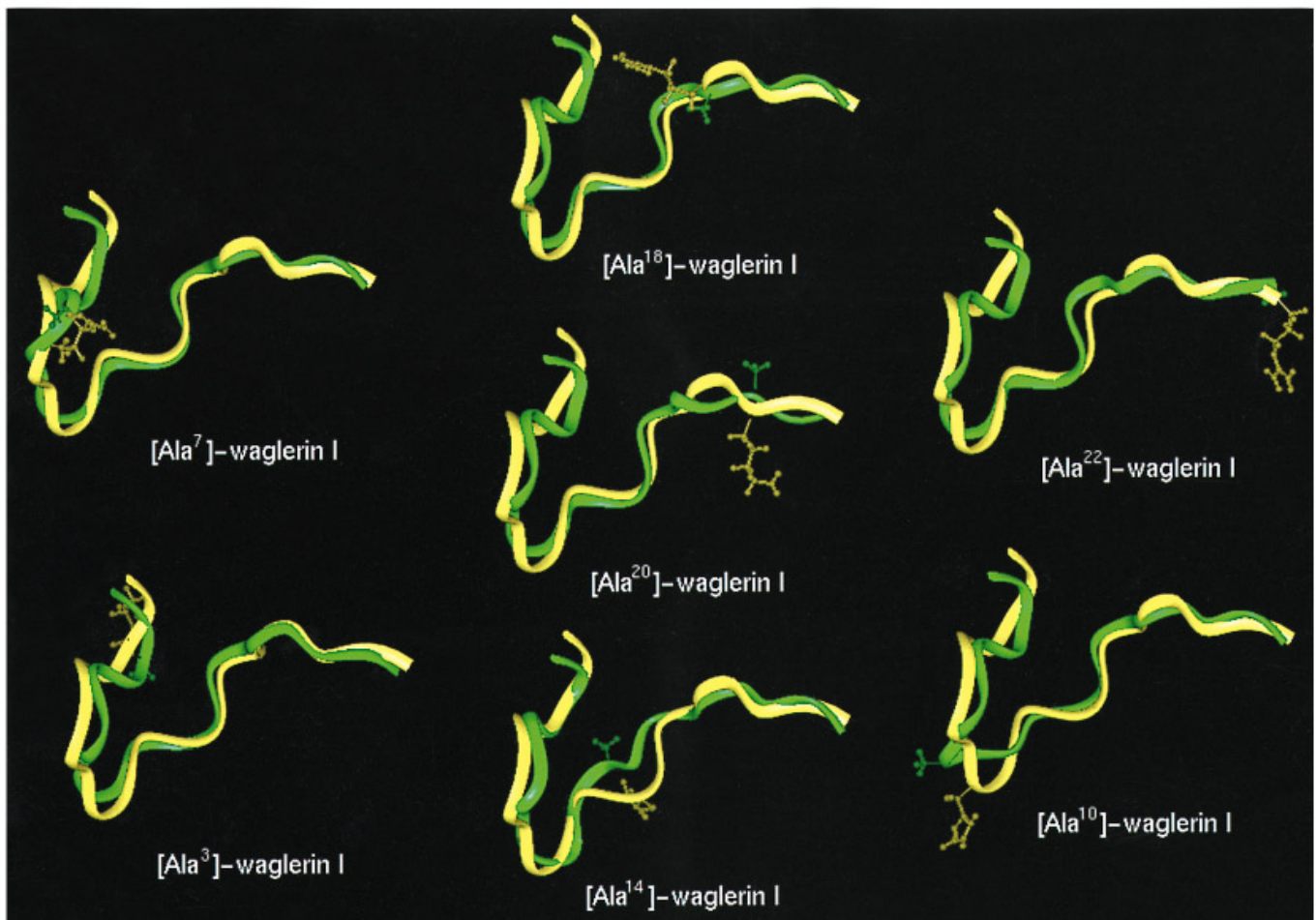

Superimposition of Waglerin I analogs with Waglerin I

green: analogs; yellow: Waglerin I

FIG. 3. Superimposition of various energy-minimized structures of synthetic analogues (green) with the basic waglerin-I (yellow). It is to be noted that only [Ala $\left.{ }^{10}\right]$-waglerin and $\left[\mathrm{Ala}^{14}\right]$-waglerin show some twist at or near the disulfide loop region when compared with the structure of waglerin-I. All other analogues show essentially similar conformations.

energetically minimized by conjugate gradient minimization. The structural comparison was achieved by pairwise conformation superimposition of the corresponding model-built waglerin-I analogues and the NMR-determined waglerin-I.

\section{RESULTS AND DISCUSSION}

Synthesis of Waglerin Analogues

All synthetic analogues can be obtained by solid-phase peptide synthesis followed by air oxidation. Analytical HPLC was used to monitor the progress of oxidation and formation of disulfide bond. Due to higher hydrophilicity associated with the oxidized forms, the reduced waglerin analogues possess slightly longer retention times than oxidized analogues when analyzed by reverse-phase HPLC. Fig. 2 showed HPLC profiles for the formation of one disulfide bond in $\left[\mathrm{Ala}^{10}\right]$-waglerin during the course of air oxidation. All reduced analogues can be converted into oxidized forms within $18 \mathrm{~h}$ in ammonium acetate solution $\left(\mathrm{pH} 8.0,4^{\circ} \mathrm{C}\right)$. It is to be noted that no intermolecular disulfide bonds were formed during air oxidation based on HPLC analyses for each analogue. The synthetic analogues were all confirmed by mass spectroscopy and amino acid analysis. The mass spectral data for each analogue are as follows: 
[Ala ${ }^{3}$-waglerin, 2461.25; $\left[\mathrm{Ala}^{7}\right]$-waglerin, 2433.50; [Ala $\left.{ }^{10}\right]$-waglerin, 2452.13; [Ala $\left.{ }^{14}\right]-$ waglerin, 2452.60; $\left[\mathrm{Ala}^{18}\right]$-waglerin, 2434.38; $\left[\mathrm{Ala}^{20}\right]$-waglerin, 2461.80; and $\left[\mathrm{Ala}^{22}\right]$-waglerin, 2434.13.

\section{$L D_{50}$ Bioassays of Waglerin Analogues}

The results of $\mathrm{LD}_{50}$ (i.p.) were shown in Table 1 . The order of toxicity among these synthetic analogues is waglerin $\mathrm{I} \approx\left[\mathrm{Ala}^{3}\right]$-waglerin $\mathrm{I} \approx\left[\mathrm{Ala}^{22}\right]$-waglerin $\mathrm{I}>\left[\mathrm{Ala}^{20}\right]$-waglerin $\mathrm{I} \approx$ $\left[\mathrm{Ala}^{7}\right]$-waglerin $\mathrm{I}>\left[\mathrm{Ala}^{18}\right]$-waglerin $>\left[\mathrm{Ala}^{14}\right]$-waglerin $>\left[\mathrm{Ala}^{10}\right]$-waglerin. This points to the fact that the active site of this toxin probably resides within the disulfide loop, particularly at $\mathrm{His}^{10}$ residue. Furthermore, according to the results of $\mathrm{LD}_{50}$ the closer is the disulfide loop to the basic amino acid in waglerin, the more influential is the basic amino acid on the toxicity of waglerin. Waglerin II ([Tyr $\left.{ }^{10}\right]$-waglerin I) was also synthesized for the comparison of its $\mathrm{LD}_{50}$ toxicity with waglerin I. In great contrast to the previous report $\left(\mathrm{LD}_{50}=0.51 \mu \mathrm{g} / \mathrm{g}\right)$ [2], we obtained a higher $\operatorname{LD}_{50}(>10 \mu \mathrm{g} / \mathrm{g})$ for this derivative, which corroborates our suggestion for the role of $\mathrm{His}^{10}$ residue in toxicity.

\section{Computer Modeling of Analogues and Structure/Function Correlation}

In order to elucidate the relationship between results of bioassay and different synthetic analogues, the tertiary structures of these analogues were simulated based on the structure of waglerin I which had been determined by NMR and computer modeling [10]. It is clear and evident (Fig. 3) that by comparison with waglerin I, $\left[\mathrm{Ala}^{10}\right]$-waglerin analogue has an apparent twist in the disulfide loop due to a single amino acid substitution at this position. The tertiary structure of $\left[\mathrm{Ala}^{14}\right]$-waglerin generated from theoretical calculation also showed a twist closely adjacent to the disulfide loop. On the other hand, the substitutions at other positions did not show significantly different structures to that of waglerin I. Therefore the structural variation of waglerin at residues close to the disulfide loop can be correlated with its biological activity, which presumably constitute as part of the active site for this toxin. It is to be concluded that two histidine residues at positions 10 and 14 indeed play significant roles in the toxicity and structural integrity of waglerin I.

\section{REFERENCES}

1. Leviton, A. E. (1964) Philip. J. Sci. 93, 251-276.

2. Weinstein, S. A., Schmidt, J. J., Bermheimer, A. W., and Smith, L. A. (1991) Toxicon. 29, $227-236$.

3. Schmidt, J. J., Weinstein, S. A., and Smith, L. A. (1992) Toxicon. 30, 1027-1036.

4. Tsai, M. C., Hsieh, W. H., Smith, L. A., and Lee, C. Y. (1995) Toxicon. 33, 363-371.

5. Lin, W. W., Smith, L. A., and Lee, C. Y. (1995) Toxicon. 33, 111-114.

6. Aiken, S. P., McArdle, J. J., Sellin, L. C., Schmidt, J. J., and Weinstein, S. A. (1991) Pharmacologist 33 , 186.

7. Aiken, S. P., Sellin, L. C., Schmidt, J. J., Weinstein, S. A., and McArdle, J. J. (1992) Pharmacology and Toxicology 70, 459-462.

8. McArdle, J. J., Xiao, Y.-F., Aiken, S. P., Sellin, L. C., Schmidt, J. J., and Weinstein, S. A. (1992) Neurosci. Soc. 18, 969.

9. Lithchfield, J. T., Jr., and Wilcoxon, F. (1949) J. Pharmc. Exp. Ther. 92, 99.

10. Chuang, L. C., Yu, H. M., Chen, C., Huang, T. H., Wu, S. H., and Wang, K. T. (1996) Biochim. Biophy. Acta 1292, $145-155$.

11. Shenkin, P. S., Yarmush, D. L., Fine, R. M., Wang, H., and Levinthal, C. (1987) Biopolymers 26, $2053-2085$.

12. Sellin, L. C., Mattila, K., Annila, A., Schmidt, J. J., McArdle, J. J., Hyvonen, M., Rantala, T. T., and Kivisto, T. (1996) Biophys. J. 70, 3-13. 